\title{
STABILISASI SEBAGAI BENTUK PENATAAN PKL MAKANAN SIAP SAJI DI KOTA SURAKARTA
}

\author{
Stabilization As An Arrangement's Form Of Processed Food Hawkers \\ In Surakarta
}

\section{Murtanti Jani Rahayu', Rr. Ratri Werdiningtyas, Musyawaroh²}

Diterima: 19 Desember 2012 Disetujui: 31 Januari 2013

\begin{abstract}
Abstrak : Pengelolaan PKL bertujuan untuk meningkatkan kesejahteraan, menjaga ketertiban umum, dan sanitasi. Pengelolaan PKL di kota Surakarta, dimulai pada tahun 2006, keberhasilan konsep penataan tidak hanya dilihat dari estetika kota yang selalu menjadi alasan utama, tetapi juga peningkatan kualitas kinerja kegiatan setelah program dilaksanakan untuk memastikan keberlanjutannya. Salah satu bentuk pengaturan yang telah dilaksanakan di kota Surakarta adalah stabilisasi. Dalam menentukan bentuk pengaturan PKL, karakter yang unik dan perilaku yang sangat beragam harus diketahui untuk memastikan bahwa pedagang dapat menerima pengaturan yang direncanakan. Makalah ini bertujuan untuk mengetahui menentukan ketepatan bentuk pengaturan stabilisasi susunan PKL yang dilakukan dengan terlebih dahulu melihat karakteristik aktivitas PKL. Analisis statistik digunakan untuk menentukan keberhasilan penataan kinerja PKL dikombinasikan dengan analisis kualitatif yang menemukan bahwa keberhasilan penataan pedagang kaki lima dalam bentuk stabilisasi estetika kota tidak sama dengan peningkatan kinerja/pemberdayaan PKL.
\end{abstract}

Kata kunci : stabilisasi , estetika lingkungan, kinerja PKL

\begin{abstract}
Abstrak: Management of hawkers has purpose to improve the welfare of hawkers, maintain public order, and sanitation. Management of hawkers in the city of Surakarta, which began in 2006, the successful concept of the arrangement is not only seen from the hawkers town aesthetic that has always been the main reason, but also improving the quality of performance of the activities after the program implemented to ensure sustainability.One of form of arrangement that has been implemented in the city of Surakarta is stabilization. In determining the form of the arrangement, unique character and behavior are very diverse hawkers must be known to ensure that hawkers can receive the planned arrangement. This paper aims to know determine the efficacy of this form of stabilization arrangement hawkers particular arrangement was done by first looking at the characteristics of hawkers activity. Statistical analysis used to determine the success of the arrangement of the hawkers performance combined with qualitative analysis found that the success of the arrangement hawkers aesthetic form of stabilization in the city is not same with the improved performance / empowerment of hawkers.
\end{abstract}

Keywords: stabilization, aesthetics of environment, performance of hawkers

\footnotetext{
${ }^{1}$ Program Studi Perencanaan Wilayah dan Kota, PIPW LPPM UNS

${ }^{2}$ Program Studi Arsitektur Fakultas Teknik Universitas Negeri Surakarta

Jl.Ir. Sutami 36 A Surakarta 57126
}

Korespondensi: mjanirahayu@gmail.com 


\section{Pendahuluan}

Jumlah PKL di kota Surakarta, saat ini masih terus meningkat. Konsep zero growth belum tercapai. Melihat karakteristik PKL, aktivitas mereka sangat beragam sesuai dengan jenis dagangan dan jenis sarana dagang yang bermacam-macam. Mc Gee and Yeung (1997) mengungkapkan PKL memiliki 4 jenis dagangan baik, jenis dagangan mentah, jenis dagangan makanan baik unprocessed maupun semi processed, non makanan dan jasa.

Untuk meminimalisasi konflik dalam penataan perlu diadakan pendekatan yang persuasif dengan mengetahui karakteristik mereka (Murtanti dkk, 2007). Hal senada diungkapkan oleh Chris Manning dan Tadjudin (1996), bahwa program penataan bagi sector informal secara umum harus dapat menciptakan kepercayaan dengan mengetahui hubungan antara kebutuhan mereka dengan bantuan yang diberikan.lebih lanjut penting mengetahui kemampuan mereka dalam menerima dan meyerap bantuan. Demikian halnya dengan kota Surakarta. Pemerintah kota Surakarta terus berupaya menekan jumlah PKL melalui berbagai bentuk penataan dengan membuat kawasan PKL dan kantong-kantong PKL. Penataan PKL di dalam Kota Surakarta diatur dalam Perda No. 3 Tahun 2008 tentang Pengelolaan PKL. Disini pemerintah berwenang untuk menetapkan, memindahkan dan menghapus lokasi PKL dengan memperhatikan kepentingan sosial, ekonomi, ketertiban dan kebersihan lingkungan di sekitarnya. Pengelolaan atau sering dikenal dengan tindakan penataan ini bertujuan untuk meningkatkan kesejahteraan PKL, menjaga ketertiban umum, dan kebersihan lingkungan.

Menurut Mc Gee and Yeung(1997) beberapa tindakan penataan dikenal dengan istilah stabilisasi, relokasi dan pemindahan. Salah satu bentuk penataan yang diterapkan di kota Surakarta adalah stabilisasi yaitu bentuk penataan fisik yaitu dengan membangun shelter permanen atau penempatan PKL pada suatu lokasi tertentu dengan membuat sarana dagang yang seragam maupun tidak. Lokasi baru PKL stabilisasi ini biasanya tidak jauh atau bahkan tetap seperti lokasi PKL sebelum dilakukan penataan. Bentuk penataan Stabilisasi ini merupakan bagian dari tindakan lokasional yang bertujuan mengatur pola lingkungan sekitar dari aktivitas PKL. Selain tindakan lokasional, pemerintah kota Surakarta juga mengkombinasikannya dengan tindakan structural, yaitu memberikan perijinan, pembinaan dan pemberian jaminan modal/kredit bagi PKL (Murtanti dkk, 2012)

Lokasi PKL yang mengalami penataan bentuk stabilisasi antara lain : Shelter kawasan Manahan, Sunday Market Manahan, Kotta Barat, Samping PDAM Adi Sucipto, Solo Square city walk, SGM city walk, City Walk, Samping DKT , Car Free Day , Ngarsopuro, Depan PGS Siang,Depan PGS Malam/Galabo, Jurug Juanda,dan Taman Makam Pahlawan. Lokasi penataan bentuk Stabilisasi di kawasan-kawasan tersebut diatas dilakukan di area : ruang terbuka, penutupan jalan-jalan tertentu, pemanfaatan trotoar serta multi fungsi ruang terbuka seperti taman, lapangan dan ruang parkir.

Dalam upaya penataan ini Dinas Pengelolaan Pasar tidak berkerja sendiri namun juga berkoordinasi dengan SKPD lain yang terkait seperti Bappeda, DTRK, DKP dan juga Dishub (Wawancara, 2012).

Untuk itu dalam artikel ini permasalahan yang diangkat adalah :

Apakah Stabilisasi yang telah dilakukan oleh Pemerintah Kota Surakarta dapat mendorong peningkatan kinerja/memberdayakan PKL sehingga mampu mendorong pembangunan ekonomi berkelanjutan di Kota Surakarta?

\section{Metode Penelitian}

Pengumpulan data tentang PKL pada penelitian ini diperoleh dari observasi lapangan pada kawasan PKL yang mengalami bentuk penataan stabilisasi di kota Surakarta. Observasi dilakukan dengan bantuan borang observasi, untuk mencatat dan mengamati beberapa karakteristik PKL yang mengalami bentuk penataan stabilisasi. Untuk 
menjaga validitasnya, dilakukan triangulasi dengan pengurus Paguyuban PKL, para pakar dan narasumber dari SKPD terkait (Pengelolaan Pasar, DTRK, Bappeda dan DKP).

Untuk mengetahui kesesuaian bentuk pengelolaan/penataan stabilisasi yang telah dilakukan oleh Pemerintah Kota dengan Karakter PKL, serta keberhasilan penataan terhadap kinerja PKL metode penelitian yang digunakan adalah Eksplanasi Kuantitatif menggunakan Analisis T-test Berpasangan dan Analisa Faktor. (Sugiyono, 2005).

Teknik sampling menggunakan rumus Frank Lynch dengan tingkat kesalahan 5\%, maka dengan populasi sebesar 692 maka didapat jumlah sampel sebesar 46 yang ditujukan kepada PKL jenis dagangan makanan, sesuai target penataan stabilisasi.

\section{Hasil Penelitian Dan Pembahasan}

Sesuai dengan Perda No. 3 tahun 2008 tentang Pengelolaan PKL dan teori Mc Gee and Yeung (1997) bahwa tujuan penataan adalah dalam rangka meningkatkan kesejahteraan masyarakat dan tindakan penataan yang dilakukan oleh pemerintah Kota Surakarta adalah kombinasi tindakan lokasional dan struktural, berupa penataan Stabilisasi yang disertai dengan pemberian perijinan, pembinaan dan juga pemberian jaminan kredit modal usaha. Dari beberapa penataan PKL dengan stabilisasi yang sudah dilakukan, berikut adalah proses stabilisasi yang pertama kali dilakukan dan yang terkini (akhir Desember 2012).

\section{Bentuk Penataan Stabilisasi PKL kota Surakarta}

\section{Proses Stabilisasi}

Proses stabilisasi PKL yang pertama adalah di Manahan sebelah barat dan utara :

1) Setelah reformasi sampai awal tahun 2006, bertebaran PKL di kawasan Manahan .tepatnya di sepanjang jalan Adi Sucipto sebelah utara. Ada yang beroperasi siang, ada juga malam hari. Ada PKL yang difungsikan sebagai tempat tinggal ada juga yang difungsikan sebagai WC umum sehingga berkembang menjadi kumuh.

2) Tahun 2006 muncul rencana penataan oleh pemerintah kota dengan membangun 180 shelter di kawasan Manahan sebelah barat stadion. Shelter ini sebagai pengganti lokasi bagi PKL yang berjualan di jalan Adi Sucipto sebelah utara dan trotoarnya

3) Tahun 2009, PKL Manahan sebelah Utara timur didampingi LSM Sompis menghadap ke DPRD dan wawali untuk diperbolehkan tetap berdagang di kawasan Manahan

4) Permintaan dipenuhi dengan syarat:

a) PKL berada di sebelah utara pagar stadion Manahan

b) Tidak mengganggu drainage

c) Kerja bakti secara periodik

d) Bentuknya bongkar pasang

e) PKL sejumlah 156 berada di area sluas $260 \mathrm{~m}^{2}$ yang tidak kebagian lapak tetap beraktivitas dengan cara share time

5) Tahun 2011 dibangun shelter Manahan sebelah utara timur (1) sebanyak 47 PKL yang disponsori oleh CSR sebuah perusahaan. Menyusul bulan Agustus 2012 telah selesai dibangun shelter PKL sebanyak 41 lapak di sebelah utara timur (2) stadion Manahan dengan biaya dari APBD sebesar 390 juta.

6) Paguyuban PKL menginisisasi pertemuan-pertemuan dengan dinas-dinas terkait PKL sebagai upaya peningkatan kondisi PKL dan kontribusi PKL kepada kota

Proses Stabilisasi di sekitar lapangan kotta barat : 
1) Setelah reformasi beberapa PKL bermunculan untuk berjualan di dalam lapangan kotta barat

2) Tahun 2004 lapangan kotta barat dinormalisasi dengan pagarisasi sehingga PKL tidak lagi bias berjualan didalamnya

3) Di tahun yang sama PKL mulai berjualan di luar lapangan utamanya di trotoar.

4) Jumlah PKL mulai bertambah dari waktu kewaktu sampai akhirnya akhir 2012, dibangun pergola di sebelah selatan dengan ukuran $68 \times 2 \mathrm{~m}$ dan sebelah barat lapangan dnegan ukuran $110 \times 3,5 \mathrm{~m}$ dengan menelan biaya 800 juta. PKL siang diharapkan berjualan di sebelah selatan lapangan. Sedangkan PKL malam bisa tetap berjualan di sebelah barat lapangan karena pada siang hari diperuntukkan bagi pejalan kaki.

Sampai saat ini PKL shelter Manahan dan Kotta Barat cukup ramai dikunjungi konsumen baik di hari libur maupun hari-hari biasa. Kondisi lingkungan sekitarpun cukup terawat karena kepedulian PKL baik dalam turut merawat maupun berkontribusi membayar retribsui keseluruhan. Menurut PKL, upaya penataan (stabilisasi) yang dilakukan oleh pemerintah di beberapa lokasi ini termasuk berhasil. Hal ini dapat dilihat dari lokasi penataan yang sampai saat ini masih cukup terawat dan dapat dimanfaatkan dengan baik. Namun demikian, juga ada yang menganggap bahwa upaya penataan yang dilakukan oleh pemerintah ini masih belum berhasil karena lokasi tersebut hanya ramai pengunjung pada saat-saat tertentu saja.

\section{Target Lokasi Stabilisasi}

Hal positif dari penataan stabilisasi ini adalah lokasi PKL yang hanya bergeser atau bahkan tetap, menjadi legal dan permanen tanpa melupakan aspek tata ruang. Lokasi PKL stabilisasi didominasi dengan lokasi yang sama dengan sebelumnya. Dan biasanya mereka berjualan setiap hari/harian. Sehingga PKL tidak merasa kehilangan konsumen dan tetap di lokasi yang strategis. Namun, ada beberapa lokasi stabilisasi yang hanya memperoleh legalisasi dalam arti diperbolehkan namun tidak memperoleh sarana dagang permanen dan hanya berjualan mingguan, seperti di PKL sunday market Manahan, boulevard UNS dan CFD. Beberapa lokasi PKL kota Surakarta yang mengalami penataan stabilisasi sesuai dengan teori Mc Gee and Yeung (1997) adalah :

1) Peruntukkan ruang terbuka (Open Market)

Dimaksudkan untuk kemudahan pergerakkan konsumen dalam menggunakan jasa pelayanan PKL ini dan diharapkan tidak mengganggu fungsi kota di lingkungan lokasi PKL. Lokasi PKL stabilisasi di kota Surakarta antara lain PKL Sunday market Manahan, city walk, hasanudin, PDAM dan Jurug Juanda/Pucangsawit.

2) Pembebasan atau penutupan jalan-jalan tertentu

Yaitu dengan menutup jalan-jalan tertentu dan menutup sirkulasi lalu lintas bagi penggunan kendaraan bermotor, yang hanya diperuntukkan bagi pergerakkan pejalan kaki. Tindakan ini biasanya bersifat temporer, dilakukan dalam waktuwaktu tertentu saja.Lokasi PKL stabilisasi di kota Surakarta semacam ini antara lain Saturday Night Ngarsopuro, Galabo dan Car Free Day

3) Pemanfaatan bagian tertentu dari jalan/trotoar

Yaitu menempatkan pedagang PKL ini pada jalan-jalan atau sebagian trotoar tertentu pada waktu tertentu, yang sekiranya tidak mengganggu aktivitas di sekitarnya. Lokasi PKL stabilisasi di kota Surakarta semacam ini antara lain PKL DKT, City Walk (Solo Square, SGM), Galabo, Depan PGS siang, PDAM, Ursulin , PGS/BTC siang dan Pasar Buah Purwosari

4) Multifungsi ruang terbuka (taman, lapangan, ruang parkir) 
Yaitu pemanfaatan ruang terbuka di sekitar kawasan perbelanjaan atau pusat keramaian pada waktu-waktu tertentu pada saat ruang tersebut kurang dimanfaatkan. Lokasi PKL stabilisasi di kota Surakarta semacam ini antara lain Sunday Market Manahan, Boulevard UNS, Jurug Juanda dan Taman Makam Pahlawan

Penetapan lokasi-lokasi PKL dengan bentuk penataan stabilisasi diatas berdasarkan pertimbangan menata tanpa menggusur (Wawancara, 2012). Dari sudut pandang tata ruang, lokasi PKL tersebut tidak mengganggu ketertiban umum dan kepentingan tata ruang kota disamping kedekatan dengan konsumen karena sesuai karakternya, PKL selalu mendekati konsumen dan aktivitas fungsional lain yang sudah terbentuk sebelumnya. Perubahan karakteristik lokasi ini juga juga disebabkan adanya perubahan aktivitas yang terjadi pada pusat-pusat aktivitas tersebut (Haryanti, 2008).

Tabel 1 Lokasi Penataan PKL Stabilisasi Kota Surakarta

\begin{tabular}{ll}
\hline Tahun & \multicolumn{1}{c}{ Lokasi Penataan } \\
\hline Sd 2006 & Manahan, Psr Buah Purwosari, Ursulin \\
2007 & Manahan, PDAM \\
2008 & Manahan, TMP, City Walk,Boulevar UNS \\
2009 & Manahan, Solo Square \\
2010 & DKT/ Jalan Wahidin, Ngarsopuro, Galabo \\
2011 & Manahan, Jurug Juanda \\
2012 & Manahan dan Kotta barat \\
\hline & Sumber : Dinas Pasar, 2010 dan Penelit,2012
\end{tabular}

\section{Identifikasi Karakteristik PKL hasil penataan Stabilisasi di Surakarta}

Kota Surakarta sudah dikenal dengan program penataan PKL yang paling bersahabat. Kota Surakarta menganut konsep Zero Growth PKL. Meskipun demikian jumlah PKL belum dapat dikendalikan. Dengan luas sekitar $44,04 \mathrm{~km} 2$, terdapat sekitar 18 kantong dan kawasan PKL hasil penataan stabilisasi di seluruh kota Surakarta.

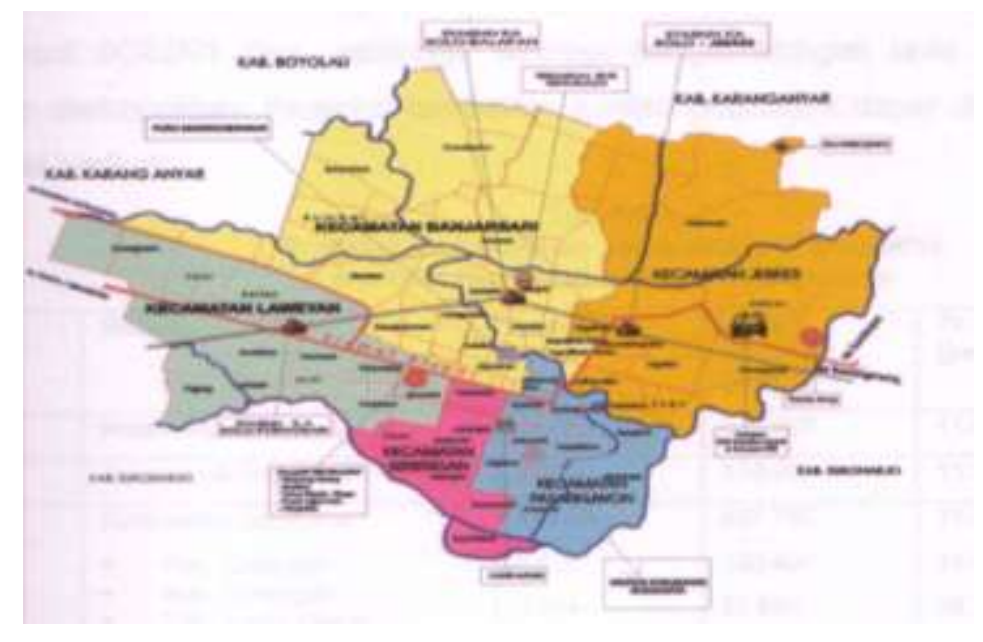


Menurut data dari Dinas Pengelolaan Pasar (DPP) pada tahun 2010, diketahui pertumbuhan jumlah PKLyang fluktuatif pada tahun 2005 ke 2007. Penurunan jumlah PKL ini dikarenakan telah dilakukan penataan PKL di beberapa tempat dengan cara relokasi seperti PKL Monumen 45 Banjarsari ke Pasar Notoharjo dan PKL belakang kampus ke pasar Panggung Rejo.

Pada observasi yang dilakukan sampai dengan bulan Juli 2012 diperoleh data jumlah PKL harian adalah 2.816. Hal ini menunjukkan jumlah PKL kembali mengalami peningkatan. Berarti pengendalian jumlah PKL yang dikenal dengan istilah zero growth belum berhasil dilakukan (Murtanti, 2012).

Tabel 2. Pertumbuhan Jumlah PKL Harian Kota Surakarta

\begin{tabular}{llll}
\hline No. & Tahun & Jumlah & Prosentase Penurunan \\
\hline 1. & 2005 & 5.817 & - \\
2. & 2007 & 3.917 & $-33 \%$ \\
3. & 2010 & 2.104 & $-46 \%$ \\
4. & 2012 & 2.816 & $+34 \%$ \\
\hline
\end{tabular}

Sumber : Pakarsemi\&Dinas PP, 2010

Sedangkan jumlah keseluruhan PKL stabilisasi (harian dan mingguan) adalah 3524 PKL. Sejumlah 694 adalah PKL harian dan sisanya sejumlah 2832 merupakan PKL mingguan . Pada PKL harian, didominasi oleh jenis dagangan makanan baik siap saji maupun mentah (buah-buahan) yaitu sekitar $97,2 \%$. Sisanya sekitar 2,8\% adalah PKL mebel yang terdapat di Jl Hasanudin. Pola penyebaran PKL disesuaikan dengan lokasi tempat mereka ditata, dan secara umum kantong/kawasan PKL stabilisasi berbentuk linier karena mengikuti jalur jalan atau pedestrian yang ada. Namun demikian, mereka juga mempunyai pola berkelompok. Pada beberapa lokasi stabilisasi yang bukan jalan ataupun trotoar seperti lapangan di Sunday market Manahan, mereka juga berderet mengikuti pola jalan/akses yang ada, disamping ada sebagian kecil yang mengelompok di tengah-tengah area. Pola penyebaran seperti ini biasanya banyak dipengaruhi oleh adanya pertimbangan aglomerasi, yaitu suatu pemusatan atau pengelompokkan pedagang sejenis atau pedagang yang mempunyai sifat komoditas yang sama atau saling menunjang. Biasanya dijumpai pada para pedagang makanan dan minuman (Mc. Gee dan Yeung, 1997).

Dari hasil identifikasi melalui observasi dan wawancara diperoleh data dan persebaran PKL penataan stabilisasi kota Surakarta sebagai berikut :

Tabel 3. Jumlah PKL Stabilisasi Di Kota Surakarta Berdasarkan Jenis Dagangan

\begin{tabular}{|c|c|c|c|c|c|c|c|c|}
\hline \multirow[t]{2}{*}{ No. } & \multirow[t]{2}{*}{ Lokasi/Jumlah } & \multirow[t]{2}{*}{ Tampilan Visual } & \multicolumn{5}{|c|}{ Jenis Dagangan } & \multirow{2}{*}{$\begin{array}{c}\begin{array}{c}\text { Ruang yg } \\
\text { dimanfaatkan }\end{array} \\
\text { Waktu }\end{array}$} \\
\hline & & & A & B & C & $\mathrm{D}$ & $\mathrm{E}$ & \\
\hline 1 & $\begin{array}{l}\text { Stadion Manahan } \\
(\mathrm{SM}) / 2051\end{array}$ & & $\mathrm{~V}$ & $\mathrm{~V}$ & $\mathrm{~V}$ & $\mathrm{~V}$ & $\mathrm{~V}$ & $\begin{array}{l}\text { Lapangan } \\
\text { Mingguan }\end{array}$ \\
\hline 2 & $\begin{array}{l}\text { Manahan } \\
(\mathrm{MN}) / 180+47+41\end{array}$ & & $\mathrm{~V}$ & $\mathrm{~V}$ & $\mathrm{~V}$ & $\mathrm{~V}$ & - & $\begin{array}{l}\text { Trotoar } \\
\text { Harian }\end{array}$ \\
\hline
\end{tabular}




\begin{tabular}{|c|c|c|c|c|c|c|c|c|}
\hline \multirow[t]{3}{*}{ No. } & \multirow[t]{3}{*}{ Lokasi/Jumlah } & \multirow[t]{3}{*}{ Tampilan Visual } & \multicolumn{5}{|c|}{ Jenis Dagangan } & \multirow{3}{*}{$\begin{array}{r}\begin{array}{c}\text { Ruang yg } \\
\text { dimanfaatkan }\end{array} \\
\text { Waktu }\end{array}$} \\
\hline & & & & & & & & \\
\hline & & & A & B & C & $\mathrm{D}$ & $\mathrm{E}$ & \\
\hline 3 & $\begin{array}{l}\text { Ngarsopuro } \\
\text { (NG)/42 +236 }\end{array}$ & & - & $\mathrm{v}$ & - & $\mathrm{v}$ & $\mathrm{v}$ & $\begin{array}{l}\text { Ruang } \\
\text { terbuka/jalan } \\
\text { yg ditutup } \\
\text { Mingguan }\end{array}$ \\
\hline 4. & $\begin{array}{l}\text { Depan PGS + BTC } \\
(\mathrm{PGS}) / 44\end{array}$ & & $\mathrm{v}$ & $\mathrm{v}$ & $\mathrm{v}$ & - & - & $\begin{array}{l}\text { Trotoar } \\
\text { Harian }\end{array}$ \\
\hline 5. & $\begin{array}{l}\text { Depan BTC+PGS } \\
\text { / GALABO/44 }\end{array}$ & & $\mathrm{v}$ & - & - & - & - & $\begin{array}{l}\text { Trotoar dan } \\
\text { penutupan } \\
\text { jalan } \\
\text { Harian }\end{array}$ \\
\hline 6. & $\begin{array}{l}\text { City Walk (HAP- } \\
\text { Perempatan SCP) } \\
(\mathrm{CW}) / 13\end{array}$ & & $\mathrm{v}$ & $\mathrm{v}$ & - & - & - & $\begin{array}{l}\text { Pedestrian } \\
\text { Harian }\end{array}$ \\
\hline 7. & $\begin{array}{l}\text { SGM (City Walk) } \\
\text { (SGM)/16 }\end{array}$ & & $\mathrm{v}$ & $\mathrm{v}$ & - & - & - & $\begin{array}{l}\text { Pedestrian } \\
\text { Harian }\end{array}$ \\
\hline 8. & $\begin{array}{l}\mathrm{DKT} \\
(\mathrm{DKT}) / 19\end{array}$ & & $\mathrm{v}$ & $\mathrm{v}$ & - & $\mathrm{v}$ & $\mathrm{v}$ & $\begin{array}{l}\text { Taman } \\
\text { Trotoar } \\
\text { Harian }\end{array}$ \\
\hline $9 .$. & $\begin{array}{l}\text { Solo Square } \\
\text { (SS)/48 }\end{array}$ & & $\mathrm{v}$ & $\mathrm{v}$ & - & - & - & $\begin{array}{l}\text { Pedestrian } \\
\text { Harian }\end{array}$ \\
\hline 10. & $\begin{array}{l}\text { Ursulin (Buah) } \\
\text { (UR)/32 }\end{array}$ & & $\mathrm{v}$ & $\mathrm{v}$ & $\mathrm{v}$ & - & $\mathrm{v}$ & $\begin{array}{l}\text { Trotoar } \\
\text { Harian }\end{array}$ \\
\hline
\end{tabular}




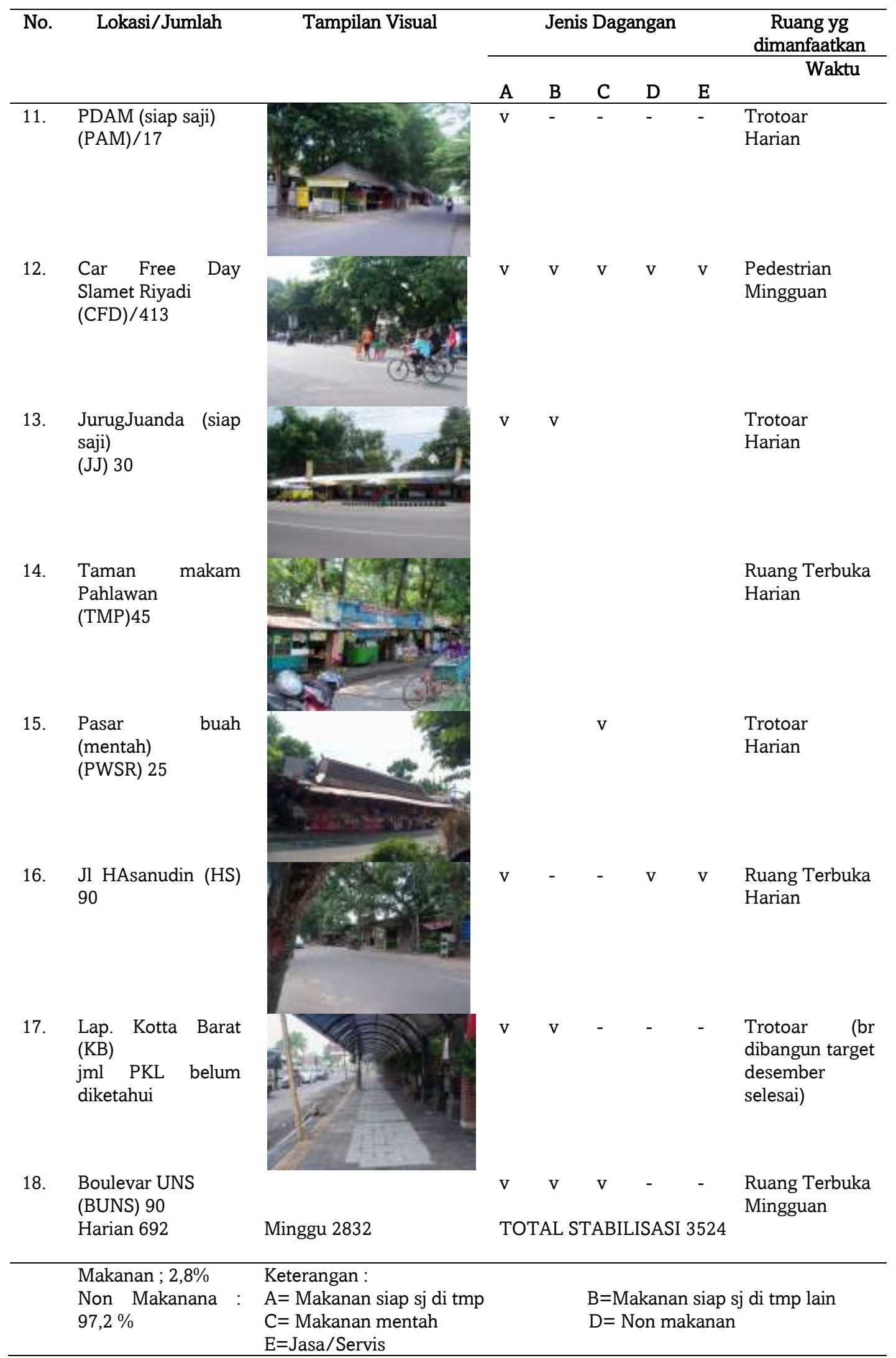

Sumber : Observasi 2012 


\section{Kesesuaian Stabilisasi yang telah dilakukan oleh Pemerintah Kota Surakarta dengan Karakter} PKL

Menurut para PKL, upaya penataan yang dilakukan oleh pemerintah adalah untuk dapat menyediakan lokasi berdagang bagi para PKL yang lebih rapi dan legal, sehingga PKL tidak menempati lokasi-lokasi yang memang tidak diperbolehkan bagi PKL. Selain itu upaya penataan tersebut juga dalam rangka untuk melakukan penghijauan kota dimana lokasi berdagang dari para PKL yang lama dibuat menjadi taman dan jalur hijau (Wawancara, 2012 dalam Murtanti, 2012)

Mayoritas PKL setuju dengan adanya upaya penataan (stabilisasi) yang dilakukan oleh pemerintah. Para pedagang ini merasa memiliki tempat berjualan yang lebih tertata dan rapi, sehingga menjadi lebih nyaman untuk berjualan disamping tenang karena tidak takut digusur. Apalagi lokasi yang baru tidak jauh bahkan tetap dari lakasi sebelumnya. Selain itu juga para PKL ini menyetujui upaya stabilisasi tersebut, karena dapat menjaga keindahan kota tanpa menghilangkan atau mematikan usaha yang menjadi mata pencaharian mereka. Sehingga jika dilihat pada kasus penataan di kota Surakarta yang didominasi oleh PKL makanan,, maka stabilisasi yang dilakukan sudah disesuaikan dengan karakteristik jenis dagangan PKL.
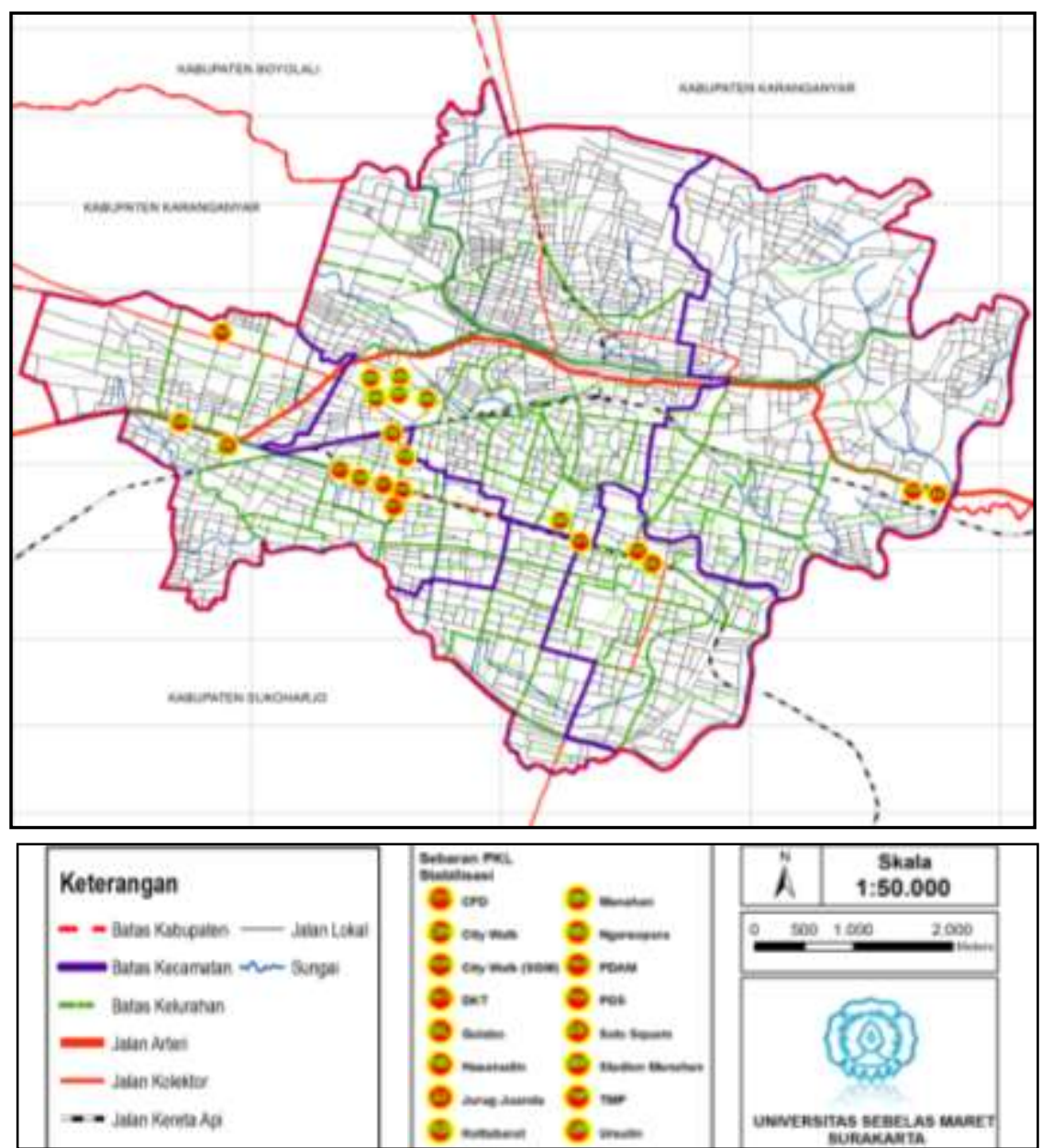

Sumber: Murtanti dkk, 2012

Gambar 2. Persebaran Lokasi PKL Stabilisasi Kota Surakarta 
Namun menurut PKL terdapat beberapa permasalahan yang memang harus dibenahi dari lokasi lama yang belum mendukung kondisi usahanya. Permasalahan tersebut antara lain adalah penyedian sumber air bersih, tempat sampah yang cukup, listrik, sarana dagang dan tempat berjualan/ shelter, serta lahan parkir yang cukup. Keberadaan lahan parkir ini meskipun tidak mempengaruhi dagangan dari para PKL ini secara langsung, namun tetap mejadi permasalahan yang sangat penting untuk diperhatikan. Hal ini dikarenakan mayoritas lokasi berjualan PKL ini adalah dekat dengan jalan, sehingga minimnya lahan parkir yang tersedia akan mengakibatkan kemacetan dimana dampaknya bukan hanya bagi konsumen dari PKL namun juga bagi pengguna jalan yang melintas di lokasi tersebut.

Upaya penataan (stabilisasi) yang dilakukan oleh Pemerintah Kota Surakarta di beberapa lokasi, tidak semua kondisi menjadi lebih baik. Namun menurut PKL ada hal yang hilang atau tidak ada di lokasi baru dibandingkan dengan lokasi yang lama. Di lokasi berjualan yang baru ini beberapa PKL merasa tempat berdagang yang menjadi lebih sempit, lokasi tidak lebih strategis dari sebelumnya dan sarana dagang. Terkait dengan permasalahan tersebut, PKL masih belum dapat melakukan banyak hal untuk mengatasinya. Para PKL tersebut hanya bisa tetap mempertahankan usahanya, karena lokasi, luasan tempat berjualan, dan sarana dagang sudah diatur.Berikut adalah gambaran sebelum dan sesudah PKL dilakukan penataan stabilisasi.

Tabel 4. Kondisi PKL sebelum dan sesudah Stabilisasi

\begin{tabular}{|c|c|c|c|c|}
\hline No & Jenis Dagangan & Kondisi Sebelum Penataan & Kondisi Sesudah Penataan & Perubahan \\
\hline 1. & 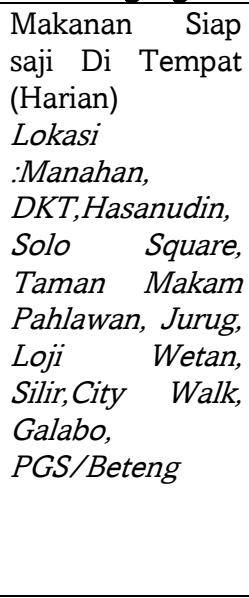 & $\begin{array}{l}\text { - } \text { Sarana dagang: } \\
\text { Gelaran/Oprokan, Tenda, } \\
\text { Grobak } \\
\text { - } \text { Waktu dagang : Pagi - } \\
\text { sore, siang-malam } \\
\text { - } \text { Pola penyebaran : linier } \\
\text { - } \text { Pola Pengelompokan } \\
\text { - Jenis Dag : sejenis } \\
\text { - Luas Lahan : 2x3 m } \\
\text { - Legalitas : Retribusi } \\
\text { - } \text { Rata-rata Lama berdagang } \\
\text { : } 8 \text { jam } \\
\text { - Skala pelayanan : Lokal, } \\
\text { regional }\end{array}$ & $\begin{array}{ll}\text { - } & \text { Sarana dagang : } \\
& \text { Shelter, Gerobak } \\
\text { - } & \text { Waktu dagang : Pagi - } \\
& \text { sore, sore-malam } \\
\text { - } & \text { Pola penyebaran : } \\
& \text { linier } \\
\text { - } & \text { Pola Pengelompokan } \\
& \text { Jenis Dagangan:sejenis } \\
\text { - } & \text { Luas Lahan : } 2 \times 3 \mathrm{~m} \\
\text { - } & \text { Legalitas : Retribusi } \\
\text { - } & \text { Rata-rata Lama } \\
& \text { berdagang : } 8 \text { jam } \\
\text { - } & \text { Skala pelayanan : } \\
& \text { Lokal, regional }\end{array}$ & 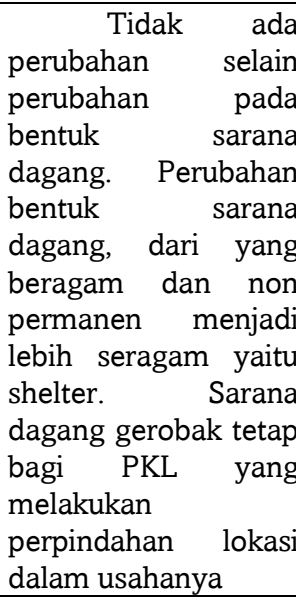 \\
\hline 2. & $\begin{array}{l}\text { Makanan Siap } \\
\text { saji Di Tempat } \\
\text { (Mingguan) } \\
\text { Lokasi :Galabo, } \\
\text { Manahan, City } \\
\text { Walk }\end{array}$ & $\begin{array}{ll}\text { - } & \text { Sarana dagang : Tenda } \\
\text { - } & \text { Waktu dagang : Pagi - } \\
& \text { sore, siang-malam } \\
\text { - } & \text { Pola penyebaran : linier } \\
\text { - } & \text { Pola Pengelompokan } \\
& \text { Jenis Dag : sejenis } \\
\text { - } & \text { Luas Lahan : } 2 \times 3 \mathrm{~m} \\
\text { - } & \text { Legalitas : Retribusi } \\
\text { - } & \text { Rata-rata Lama berdagang } \\
& : 8 \text { jam } \\
\text { - Skala pelayanan : Lokal, } \\
\\
\text { regional }\end{array}$ & $\begin{array}{ll}\text { - } & \text { Sarana dagang: } \\
& \text { Shelter } \\
\text { - } & \text { Waktu dagang : Pagi - } \\
& \text { sore, siang-malam } \\
\text { - } & \text { Pola penyebaran : } \\
& \text { linier } \\
\text { - } & \text { Pola Pengelompokan } \\
& \text { Jenis Dag :sejenis } \\
\text { - } & \text { Luas Lahan : 2x3 m } \\
\text { - } & \text { Legalitas : Retribusi } \\
\text { - } & \text { Rata-rata Lama } \\
& \text { berdagang : } 8 \text { jam } \\
\text { - } & \text { Skala pelayanan : } \\
& \text { Lokal, regional } \\
\end{array}$ & \begin{tabular}{lr}
\multicolumn{1}{c}{ Tidak } & ada \\
perubahan & selain \\
perubahan & pada \\
bentuk & sarana \\
dagang. & Perubahan \\
bentuk sarana dagang \\
dari tenda & menjadi \\
shelter & yang \\
berbentuk & seragam \\
dan permanen.
\end{tabular} \\
\hline 3. & $\begin{array}{l}\text { Non Makanan } \\
\text { (Harian) } \\
\text { Lokasi } \\
\text { :DKT,Hasanudin }\end{array}$ & $\begin{array}{l}\text { - } \text { Sarana dagang : Tenda } \\
\text { - Waktu dagang : Pagi - } \\
\text { sore } \\
\text { - Pola penyebaran : linier }\end{array}$ & $\begin{array}{l}\text { - } \text { Sarana dagang: } \\
\text { Shelter } \\
\text { - Waktu dagang : Pagi - } \\
\text { sore }\end{array}$ & \begin{tabular}{lr}
\multicolumn{1}{c}{ Tidak } & ada \\
perubahan & selain \\
perubahan & pada \\
bentuk & sarana
\end{tabular} \\
\hline
\end{tabular}




\begin{tabular}{|c|c|c|c|c|}
\hline No & Jenis Dagangan & Kondisi Sebelum Penataan & Kondisi Sesudah Penataan & Perubahan \\
\hline & $\begin{array}{l}\text { Manahan, Silir, } \\
\text { Pedaringan, } \\
\text { Belakang UNS }\end{array}$ & $\begin{array}{ll}\text { - } & \text { Pola Pengelompokan } \\
& \text { Jenis Dag :campur } \\
\text { - } & \text { Luas Lahan : 3x3 m } \\
\text { - } & \text { Legalitas : Retribusi } \\
\text { - } & \text { Rata-rata Lama berdagang } \\
& \text { : } 8 \text { jam } \\
\text { - } & \text { Skala pelayanan : Lokal }\end{array}$ & $\begin{array}{ll}\text { - } & \text { Pola penyebaran : } \\
& \text { linier } \\
\text { - } & \text { Pola Pengelompokan } \\
& \text { Jenis Dag : bercampur } \\
\text { - } & \text { Luas Lahan : } 3 \times 3 \mathrm{~m} \\
\text { - } & \text { Legalitas : Retribusi } \\
\text { - } & \text { Rata-rata Lama } \\
& \text { berdagang : 8 jam } \\
\text { - } & \text { Skala pelayanan : } \\
& \text { Lokal } \\
\end{array}$ & $\begin{array}{lr}\text { dagang. Perubahan } \\
\text { bentuk sarana dagang } \\
\text { dari tenda menjadi } \\
\text { shelter yang } \\
\text { berbentuk seragam } \\
\text { dan permanen. }\end{array}$ \\
\hline 4. & $\begin{array}{l}\text { Non Makanan } \\
\text { (Mingguan) } \\
\text { Lokasi :CFD, } \\
\text { Manahan, } \\
\text { Ngarsopuro }\end{array}$ & $\begin{array}{l}\text { - Sarana dagang : Tenda, } \\
\text { - Gelaran, Gerobak } \\
\text { - Waktu dagang : Pagi - } \\
\text { - } \text { Siang. Sore - malam } \\
\text { - } \text { mela penyebaran : } \\
\text { - Pola Pengelompok dan linier } \\
\text { Jenis Dagangan : } \\
\text { bercampur } \\
\text { - Luas Lahan : 2x2 m, 3x3 m } \\
\text { - Legalitas : Retribusi } \\
\text { - Rata-rata Lama berdagang } \\
\text { : } 8 \text { jam } \\
\text { - Skala pelayanan : Lokal, } \\
\text { regional }\end{array}$ & $\begin{array}{l}\text { - } \text { Sarana dagang : } \\
\text { Tenda, } \\
\text { Gelaran,Gerobak, } \\
\text { shelter } \\
\text { - } \text { Waktu dagang : Pagi - } \\
\text { siang, Sore - malam } \\
\text { - Pola penyebaran : } \\
\text { mengelompok dan } \\
\text { linier } \\
\text { - Pola Pengelompokan } \\
\text { Jenis Dagangan : } \\
\text { bercampur } \\
\text { - Luas Lahan : 2x2 m, } \\
\text { 3x3 m } \\
\text { - Legalitas : Retribusi } \\
\text { - Rata-rata Lama } \\
\text { berdagang : } 4-8 \text { jam } \\
\text { - Skala pelayanan : } \\
\text { Lokal, regional } \\
\end{array}$ & 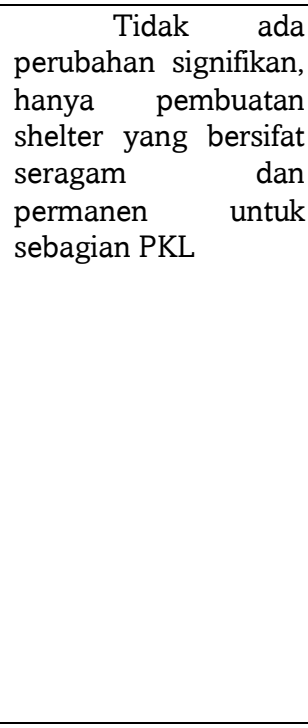 \\
\hline
\end{tabular}

Sumber : Hasil Analisis, 2012

Penataan PKL di Solo tidak hanya dilakukan untuk membangun lapak PKL, namun juga terkait dengan pembangunan kelengkapan sarana dan prasarana, pembinaan SDM, bantuan modal, pendampingan dan pengaturan. PKL ditata dengan pendekatan yang sangat spesifik melalui mekanisme pendekatan personal, pendekatan lingkungan, kemudian pendekatan kelembagaan dan terakhir pendekatan formal/instansional. (Perda No. 3/2008)

Spesifikasi pendekatan tersebut adalah : Pendekatan nguwongke uwong, kemitraan, hati nurani dan saling menghormati. Selain karakter kepemimpinan yang santun dan memiliki komitmen tinggi terhadap ekonomi kerakyatan di kota Surakarta, komitmen seluruh stakeholders kota menjadi kekuatan pendukung dalam mengurai permasalahan PKL.

Dari kacamata PKL, upaya penataan yang dilakukan oleh pihak pemerintah sudah cukup baik. Secara keseluruhan pemerintah sudah mampu mengakomodasi hal-hal diperlukan oleh para PKL.

\section{a. Keberhasilan Stabilisasi PKL dalam mendorong pembangunan ekonomi berkelanjutan}

Untuk mengevaluasi apakah pengelolaan yang telah dilaksanakan oleh Pemkot Surakarta sudah sesuai dengan karakter/kebutuhan PKL, menggunakan metode \& teknik analisis analisis T-test berpasangan. Hasil analisa menggunakan teknik analisa compared means : Paired T-test, dimana Nilai Sig $(2$ tailed $)<0,05$ menunjukkan terjadi perubahan secara signfikan antara kondisi rata-rata sebelum penataan dan sesudah penataan begitu pula sebaliknya. Koefisien Correlation menunjukkan besarnya perubahan yang terjadi sebelum dan sesudah penataan stabilisasi dilakukan. Kondisi yang diobservasi/dinilai 
meliputi 13 variabel, dan yang menunjukkan perubahan setelah penataan yaitu pada yaitu : Retribusi, Kualitas Sarana, Kebersihan, Fasilitas Pendukung, dan Peran Paguyuban. Hasil analisis adalah sebagai berikut :

Tabel 5. Pengaruh Stabilisasi terhadap Kondisi PKL

\begin{tabular}{|c|c|c|c|c|c|c|c|c|}
\hline \multirow[t]{2}{*}{ No. } & \multirow[t]{2}{*}{$\begin{array}{l}\text { Kondisi } \\
\text { PKL }\end{array}$} & \multirow{2}{*}{$\begin{array}{l}\text { Perubahan } \\
\text { (Mean) }\end{array}$} & Rata-rata & \multicolumn{2}{|c|}{ Besarnya Korelasi dan Tingkat } & $\begin{array}{l}\text { an Tingkat } \\
\text { Sebelum }\end{array}$ & \multicolumn{2}{|c|}{$\begin{array}{lr}\text { Pengaruh } & \text { Stabilisasi } \\
\text { Terhadap } & \text { Kondisi } \\
\text { PKL } & \end{array}$} \\
\hline & & & Sesudah & $\begin{array}{l}\text { Koef. } \\
\text { Correlation }\end{array}$ & Sig. & Analisis & $\begin{array}{c}\text { Sig. } \\
(2- \\
\text { tailed) } \\
\end{array}$ & Analisis \\
\hline 1. & Luas lapak & 7.72 & 7.98 & .422 & .020 & $\begin{array}{l}\text { Korelasi } \\
\text { tidak } \\
\text { kuat dan } \\
\text { signifikan }\end{array}$ & .727 & $\begin{array}{c}\text { Tidak } \\
\text { berpengaruh }\end{array}$ \\
\hline 2. & $\begin{array}{l}\text { Jam } \\
\text { operasional }\end{array}$ & 8.10 & 7.78 & .942 & .000 & $\begin{array}{l}\text { Korelasi } \\
\text { kuat, dan } \\
\text { signifikan }\end{array}$ & .111 & $\begin{array}{c}\text { Tidak } \\
\text { berpengaruh }\end{array}$ \\
\hline 3. & $\begin{array}{l}\text { Jumlah } \\
\text { dagangan }\end{array}$ & 100.00 & 106.83 & . & . & - & .073 & $\begin{array}{c}\text { Tidak } \\
\text { berpengaruh }\end{array}$ \\
\hline 4. & $\begin{array}{l}\text { Jumlah } \\
\text { pengunjung }\end{array}$ & 68.33 & 68.33 & .940 & .000 & $\begin{array}{l}\text { Korelasi } \\
\text { kuat, dan } \\
\text { signifikan }\end{array}$ & 1.000 & $\begin{array}{c}\text { Tidak } \\
\text { berpengaruh }\end{array}$ \\
\hline 5. & Retribusi & 1373.33 & 2100.00 & .575 & .001 & $\begin{array}{l}\text { Korelasi } \\
\text { kuat, dan } \\
\text { signifikan }\end{array}$ & .000 & Berpengaruh \\
\hline 6. & $\begin{array}{l}\text { Pendapatan } \\
\text { bersih }\end{array}$ & 215000.00 & 194500.00 & .594 & .001 & $\begin{array}{l}\text { Korelasi } \\
\text { kuat, dan } \\
\text { signifikan }\end{array}$ & .292 & $\begin{array}{c}\text { Tidak } \\
\text { berpengaruh }\end{array}$ \\
\hline 7. & Keamanan & 2.43 & 2.73 & .719 & .000 & $\begin{array}{l}\text { Korelasi } \\
\text { kuat, dan } \\
\text { signifikan }\end{array}$ & .005 & $\begin{array}{c}\text { Tidak } \\
\text { Berpengaruh }\end{array}$ \\
\hline 8. & $\begin{array}{l}\text { Kualitas } \\
\text { sarana }\end{array}$ & 2.60 & 3.00 & .538 & .002 & $\begin{array}{l}\text { Korelasi } \\
\text { kuat, dan } \\
\text { signifikan }\end{array}$ & .001 & Berpengaruh \\
\hline 9. & $\begin{array}{l}\text { Kebersihan } \\
\text { lokasi }\end{array}$ & 2.47 & 3.13 & .381 & .038 & $\begin{array}{l}\text { Korelasi } \\
\text { tidak } \\
\text { kuat, dan } \\
\text { signifikan }\end{array}$ & .000 & Berpengaruh \\
\hline 10. & $\begin{array}{l}\text { Fasilitas } \\
\text { pendukung }\end{array}$ & 2.23 & 2.80 & .424 & .020 & $\begin{array}{l}\text { Korelasi } \\
\text { tidak } \\
\text { kuat, dan } \\
\text { signifikan }\end{array}$ & .001 & Berpengaruh \\
\hline 11. & Peran PKL & 3.07 & 3.03 & .914 & .000 & $\begin{array}{l}\text { Korelasi } \\
\text { kuat, dan } \\
\text { signifikan }\end{array}$ & .326 & $\begin{array}{c}\text { Tidak } \\
\text { berpengaruh }\end{array}$ \\
\hline 12. & $\begin{array}{l}\text { Peran } \\
\text { Dinas }\end{array}$ & 2.43 & 2.60 & -.078 & .682 & $\begin{array}{l}\text { Korelasi } \\
\text { tidak } \\
\text { kuat, dan } \\
\text { tidak } \\
\text { signifikan }\end{array}$ & .305 & $\begin{array}{c}\text { Tidak } \\
\text { berpengaruh }\end{array}$ \\
\hline 13. & $\begin{array}{l}\text { Peran } \\
\text { Paguyuban }\end{array}$ & 1.97 & 2.70 & .462 & .010 & $\begin{array}{l}\text { Korelasi } \\
\text { tidak } \\
\text { kuat dan } \\
\text { signifikan }\end{array}$ & .000 & Berpengaruh \\
\hline
\end{tabular}

Sumber : Hasil Analisis ,2012Faktor- Faktor Berpengaruh dalam Keberhasilan Penataan PKL

Analisa faktor dengan program SPSS dalam penelitian ini dilakukan untuk mengetahui faktor-faktor yang mempengaruhi keberhasilan penataan PKL dari sudut 
pandang PKL sebagai aktor utama yang terlibat dalam penataan, dengan mengambil 19 komponen yang diatur dalam penataan PKL. Hal ini untuk menjadikan penataan PKL menjadi salah satu strategi pemberdayaan ekonomi masyarakat.

Sebagaimana diketahui bahwa tujuan dilakukan penataan PKL adalah memberikan ruang yang lebih baik bagi PKL untuk berdagang sehingga diharapkan dengan adanya ruang yang baik akan mampu meningkatkan kinerja PKL. Oleh karena itu pengetahuan tentang faktor-faktor yang dianggap penting oleh PKL dalam sebuah penataan perlu untuk diketahui. Sehingga komponen dalam program penataan PKL yang dilakukan dapat tepat, efisien dan efektif memenuhi kebutuhan PKL. Sebagaimana temuan sebelumnya tidak semua penataan PKL yang berhasil secara fisik estetika juga berhasil sebagai program pemberdayaan ekonomi PKL (Murtanti dkk, 2012).

Dari 19 variabel yang diuji yaitu : Kondisi luas lapak, kondisi sarana dagang, pengaturan waktu pelayanan, kondisi pola pengelompokan, tingkat kestrategisan lokasi, keterjangakauan lokasi, ketersediaan sarana pendukung, ketersediaan parker, ketersediaan lampu penerangan, ketersediaan air bersih, ketersediaan tempat sampah, estetika lokasi, keberadaan fungsi utama, keamanan lokasi, kebersihan lokasi, pembinaan PKL, legalitas usaha, aglomerasi dnegan kegiatan alin dan modal usaha. Diketemukan bahwa menurut PKL hanya ada 4 variabel yang memiliki pengaruh besar dalam keberhasilan stabilisasi PKL dari sudut pandang PKL, yaitu kondisi luas lapak, ketersediaan sarana pendukung, ketersediaan lampu penerangan dan pembinaan. Keempat variabel tersebut terkelompok menjadi 1 faktor dan mempengaruhi tingkat keberhasilan sebesar 63,2\%. Berikut ringkasan hasil analisa faktor 19 variabel berpengaruh terhadap keberhasilan stabilisasi PKL.

Tabel 6. Analisis Faktor Berpengaruh Terhadap Keberhasilan Stabilisasi PKL

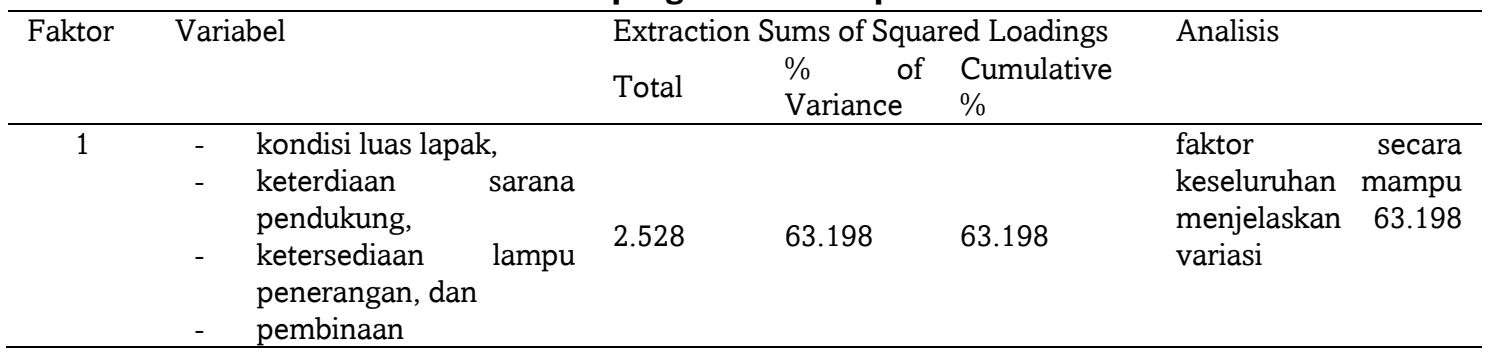

Sumber : Hasil Analisa, 2012

\section{Kesimpulan}

1. Karakteristik PKL Stabilisasi di Surakarta :

1) Penataan stabilisasi kota Surakarta penerapannya didominasi untuk PKL dengan jenis dagangan makanan dan minuman (siap saji di tempat dan tempat lain)

2) Sampai tahun 2012 stabilisasi jumlah PKL stabilisasi harian 692 dan jumlah PKL stabilisasi mingguan 2832

3) Stabilisasi sebagai salah satu bentuk penataan PKL harian didominasi oleh PKL makanan dengan prosentase $97,2 \%$ sisanya adalah PKL dengan jensi dagangan lainnya yaitu 2,8\%. Ini menunjukkan PKL makanan paling dibutuhkan dan lebih fleksible keberadaannya.

4) Lokasi stabilisasi PKL terdiri atas jalur pedestrian/trotoar, taman, penutupan jalan dan lapangan tersebar di 18 titik PKL di kota Surakarta

5) Pola Pengelompokan linier mengikuti jalur jalan/trotoar/pedestrian yang ada sekaligus mengelompok membentuk kantong/kawasan PKL.

2. Keberhasilan penatan stabilisasi

a) Dari 13 variabel yang menunjukkan perubahan lebih tinggi/baik setelah penataan yaitu pada yaitu : Retribusi, Kualitas Sarana, Kebersihan, Fasilitas Pendukung, dan Peran Paguyuban 
b) Berhasil dalam hal pengaturan dan peningkatan kualitas kawasan tetapi tidak meningkatkan pendapatan PKL (Pendapatan PKL menurun)

c) Peran PKL sama sekali belum dilibatkan dalam strategi penataan kawasan saat ini.

3. Dalam mencari factor yang mempengaruhi perubahan setelah penataan stabilisasi, dari 19 faktor yang dinilai, hanya 4 yang berpengaruh yaitu yaitu kondisi luas lapak, ketersediaan sarana pendukung, ketersediaan lampu penerangan dan pembinaan. Keempat variabel tersebut terkelompok menjadi 1 faktor dan mempengaruhi tingkat keberhasilan sebesar 63,2\%.

\section{Daftar Pustaka}

Dini Tri Haryanti. 2008. Kajian Pola Pemanfaatan Ruang Terbuka Publik Kawasan Bundaran Simpang Lima. Magister Teknik Perencanaan Wilayah dan Kota UNDIP. Semarang

Manning, Crish dan Tadjudin Noer Effendi. 1996. Urbanisasi, Pengangguran dan Sektor Informal di Kota. Jakarta: Yayasan Obor Indonesia.

Mc. Gee, T. G dan Yeung, Y. M. 1997. Hawkers In Southeast Asian Cities: Planning for The Bazaar Economiy. Canada: International Development Research Centre.

Murtanti,dkk : 2006 : Identifikasi PKL pagar belakang Kampus UNS Kentingan : UNS

Murtanti,dkk : 2007: Identifikasi PKL Perkotaan di kabupaten Sukoharjo : UNS

Murtanti,dkk : 2012 : Strategi Pemberdayaan PKL secara partisipatif dalam Mendorong Ekonomi Kerakyatan yang Berkelanjutan : UNS

Pakarsemi dan Dinas Pasar. 2010. Pendataan Potensi PKL Kota Surakarta. Dinas Pasar Kota Surakarta

Perda No. 3 Tahun 2008 tentang Pengelolaan Pedagang Kaki Lima Kota Surakarta

Sugiyono : 2005 : Statistik untuk Penelitian: Alfabeta : Bandung 